\title{
Assessment of the efficiency of energy management at an industrial enterprise
}

\author{
Inna Nekrasova ${ }^{1, *}$, Elena Trubchaninova ${ }^{2}$, Vyacheslav Sevalnev ${ }^{3}$, and Elizaveta \\ Sedelnikova ${ }^{4}$ \\ ${ }^{1}$ Industrial University of Tyumen, Volodarskogo str. 38, Tyumen, Russia \\ ${ }^{2}$ Samara State Technical University, Molodogvardeyskaya str. 244, Samara, Russia \\ ${ }^{3}$ Institute of Legislation and Comparative Law under the Government of the Russian Federation, \\ Cheremushkinskaya str., 34, Moscow, Russia \\ ${ }^{4}$ Tyumen State University, Volodarskogo str., 6, Tyumen, 625001, Russia
}

\begin{abstract}
The article proposes a methodology for assessing the efficiency of energy management at an industrial enterprise. The methodology involves the calculation of an integral indicator of the efficiency of energy management based on the assessment of single efficiency indicators. The proposed methodology allows for the ongoing monitoring of energy consumption, timely identification of the main factors affecting energy conservation. To confirm the applicability of the proposed methodology, testing was carried out at industrial enterprises of the Tyumen region, taking into account the data for 2018 .
\end{abstract}

\section{Introduction}

Today, along with the increase in energy intensity of production, there has been a radical change in the management system, and new economic entities in the field of production management, distribution and energy consumption have emerged, which has led to a new structure of economic interests that must be taken into account when implementing Russia's energy policy at the level of an industrial enterprise. Under these conditions, consumers of energy resources have a problem - an alternative to the choice of fuel and energy producers.

In this regard, there is a need to develop new approaches to the management of promising energy consumption of industrial enterprises, taking into account the economic interests of all entities, especially since these issues are of important applicable nature.

Energy management of industrial enterprises under conditions of market relations allows to form a strategy of an enterprise in conjunction with energy efficiency, as well as to determine the efficiency of energy management at the enterprise level.

Solving the problem of energy efficiency requires the creation and implementation of appropriate management mechanisms at the level of a metallurgical enterprise, that allows coordinating and regulating the process of energy consumption. The experience of European countries has shown significant success in this area, which are expressed in enactments and fiscal regulation. Today, the use of such mechanisms in the practice of

\footnotetext{
*Corresponding author: minnullinaay@yandex.ru
} 
energy management in Russia is extremely in demand [1-2]

Many scientists have been involved in addressing the issues of management of the promising energy consumption of enterprises. The energy intensity of production of an industrial enterprise as an object of study is considered by them in a comprehensive manner, taking into account many factors, which is quite natural for such a complex object. The works of many such Russian scientists as V. Anufriev, A. Vigdorchik, N. Vilensky, L. Gitelman, R. Zaripov, Yu. Klyuev, V. Okorokov, M. Fedorov and many others are dedicated to the study of energy conservation reserves and increasing the level of energy efficiency of production processes of enterprises. In these works, the tools of management of the energy component of industrial enterprises are considered in detail, attention is paid to the process of formation and assessment of fuel and energy balance of an industrial enterprise when assessing the energy efficiency and energy conservation in the works [3-8].

The works of foreign authors are devoted to the issues of fuel and energy economy, increasing the efficiency of their use at enterprises: D. Kazum, L. Brooks, G. Saunders, K. M. Meyer-Abich, H. Meixner, G. Saunders, U. Khaampike.

The main disadvantage of the existing methodological approaches to energy management at enterprises [9-11] is that the organization of the implementation of the energy strategy involves only comparative assessments of individual indicators of technological and economic efficiency. At the same time, there is no integral indicator of management and this does not allow for the implementation of a systematic approach to assessing the effective management of promising energy consumption of an industrial enterprise [11-12].

\section{Methods}

The assessment of efficiency of energy management should be conducted to determine the degree of achievement of goals to be sought at all levels of the macro- and microenvironment of an enterprise.

For the comprehensive assessment of energy consumption, a set of indicators of efficiency of the implementation of an energy strategy at an industrial enterprise is proposed, which takes into account the integral criteria for the degree of fulfillment of the goals to be sought: - technological efficiency indicators assess the impact of energy management on the level of energy conservation, changes in technological parameters;

- organizational efficiency indicators allow assessing the level of planning and organization of energy management through the energy strategy.

The selection of technological and organizational efficiency indicators was made on the basis of the analysis of energy consumption and the assessment of importance of these indicators in the scientific literature of leading scientists and experts in the field of energy efficiency and energy conservation at industrial enterprises.

At the same time, an efficiency indicator is considered as a measure of achieving the goal, the compliance with the actual and standard results of the implementation of indicators of energy program projects.

Basic requirements for efficiency indicators:

- the degree of achievement of the process goal is reflected in the efficiency indicator;

- the content of the efficiency indicator should be clear;

- the value of the efficiency indicator should be measured in a certain scale;

- the efficiency indicator should consist of a small number of disaggregated indicators.

On the basis of the requirements formed, a list of key indicators for group indicators of efficiency of energy management of an industrial enterprise was compiled (Table 1).

Table 1. The system of target indicators of efficiency of energy management of an industrial enterprise 


\begin{tabular}{|c|c|c|}
\hline $\begin{array}{c}\text { Group } \\
\text { efficiency } \\
\text { indicator }\end{array}$ & Single indicator of energy consumption efficiency & $\begin{array}{c}\text { Formalized } \\
\text { notation }\end{array}$ \\
\hline \multirow{6}{*}{$\begin{array}{l}\text { Technological } \\
\text { efficiency } \\
\text { indicator }\end{array}$} & Coefficient of utilization of internal energy resources & $\mathrm{C}_{1}^{\mathrm{ef}}$ \\
\hline & Coefficient of energy intensity of products & $\mathrm{C}_{2}^{\mathrm{ef}}$ \\
\hline & Coefficient of the share of energy costs in the cost of production & $\mathrm{C}_{3}^{\mathrm{ef}}$ \\
\hline & Coefficient of gross emissions of harmful substances & $\mathrm{C}_{4}^{\mathrm{ef}}$ \\
\hline & $\mathrm{CO} 2$ emission coefficient & $\mathrm{C}_{5}^{\mathrm{ef}}$ \\
\hline & Coefficient of the share of material costs in the cost of production & $\mathrm{C}_{6}^{\mathrm{ef}}$ \\
\hline \multirow{4}{*}{$\begin{array}{l}\text { Organizational } \\
\text { efficiency } \\
\text { indicator }\end{array}$} & Coefficient of development of investment costs & $\mathrm{C}_{7}^{\mathrm{ef}}$ \\
\hline & $\begin{array}{l}\text { The level of development of the competence of the industrial } \\
\text { production personnel in the field of energy conservation }\end{array}$ & $\mathrm{C}_{8}^{\mathrm{ef}}$ \\
\hline & $\begin{array}{l}\text { Coefficient of timeliness of performance of works on the control } \\
\text { points of investment projects }\end{array}$ & $\mathrm{C}_{9}^{\mathrm{ef}}$ \\
\hline & $\begin{array}{l}\text { Coefficient of the effect of the implementation of investment } \\
\text { projects }\end{array}$ & $\mathrm{C}_{10}^{\mathrm{ef}}$ \\
\hline
\end{tabular}

Initially, the assessment of technological indicators of energy management efficiency at an industrial enterprise is carried out.

The coefficient of utilization of internal energy resources is calculated by formula (1):

$$
C_{1}^{e f}=\frac{Q_{\text {fact }}}{Q_{\text {standart }}}
$$

$Q_{\text {fact }}, Q_{\text {standart }}$ - respectively the actual and standard volumes of utilization of internal energy resources in the implementation of the energy strategy.

2. Coefficient of energy intensity of products (2):

$$
C_{2}^{e f}=\frac{\left(\frac{C}{G O}\right)_{\text {standart }}}{\left(\frac{C}{G O}\right)_{\text {fact }}}
$$

$C, G O$ - respectively the energy consumption for gross production and gross output and $\left(\frac{C}{G O}\right)_{\text {fact }},\left(\frac{C}{G O}\right)_{\text {standart }}$ - the actual and standard energy intensity of gross output during the implementation of the energy program.

3. Coefficient of the share of energy costs in the cost of production is calculated by formula (3):

$$
C_{3}^{e f}=\frac{d_{\text {standart }}}{d_{\text {fact }}}
$$

$d_{\text {standart }}, d_{\text {fact }}$ - the planned and actual share of energy costs in the operating cost of production.

4. Coefficient of gross emissions of harmful substances (4):

$$
C_{4}^{e f}=\frac{E_{\text {standart }}}{E_{\text {fact }}}
$$

$E_{\text {standart }}, E_{\text {fact }}$ - the actual and standard amount of harmful emissions into the atmosphere of the region during the implementation of the energy program.

5. CO2 emission coefficient is calculated by formula (5): 


$$
C_{5}^{e f}=\frac{\mathrm{CO}_{\text {standart }}}{\mathrm{CO}_{\text {fact }}}
$$

$\mathrm{CO}_{\text {fact }}, \mathrm{CO} 2_{\text {standart }}$ - the actual and standard annual volume of $\mathrm{CO} 2$ emissions in the implementation of the energy program.

6. The coefficient of the share of material costs in the cost of production is calculated by formula (6):

$$
C_{6}^{e f}=\frac{\left(\frac{M C}{G O}\right)_{\text {standart }}}{\left(\frac{M C}{G O}\right)_{\text {fact }}}
$$

$M C_{\text {fact }}, M C_{\text {standart }}$ - the actual and standard material costs of the annual gross output during the implementation of the energy strategy.

Next, the assessment of organizational indicators of energy management efficiency at an industrial enterprise is made.

1. The coefficient of development of investment costs is calculated by formula (7):

$$
C_{7}^{e f}=\frac{\sum_{i=1}^{n} I_{\text {fact }}}{\sum_{i=1}^{n} I_{\text {standart }}}
$$

$\sum_{i=1}^{n} \mathrm{I}_{\text {fact }}$ - the amount of planned investments for all projects of the energy strategy; $\sum_{i=1}^{n} \mathrm{I}_{\text {standart }}$ - the sum of the disposed investments in all projects of the energy program.

2. The level of development of the competence of industrial personnel in the field of energy saving management (8):

$$
C_{8}^{e f}=\frac{P_{\text {fact }}}{P_{\text {total }}}
$$

$P_{\text {fact }}, P_{\text {total }}-$ the actual number of industrial personnel involved in energy conservation and increasing energy efficiency, and the total number of industrial personnel.

3. The coefficient of timeliness of performance of works on the control points of the energy-saving investment project is calculated by formula (9):

$$
C_{9}^{e f}=\frac{\sum_{i=1}^{n}\left(1-\frac{\Delta T_{c p p}}{T_{\text {standart }}}\right) \Delta S_{i}}{\sum_{i=1}^{n} \Delta S_{i}}
$$

$\Delta T_{c p p}$ - the deviation from the deadline for the implementation of the control point of the ith energy strategy project (days); $T_{\text {standart }}$ - the standard duration of the i-th project (days); $\Delta S_{i}$ - energy savings on the i-th project in the implementation of the energy strategy.

4. The coefficient of the effect obtained from the implementation of investment projects is calculated by formula (10):

$$
C_{10}^{e f}=\frac{\sum_{i=1}^{n} E f f_{\text {actual }}}{\sum_{i=1}^{n} E f f_{\text {standard }}}
$$

$E f f_{\text {act }}$ - the actual annual effect from projects implementation, $E f f_{\text {standart }}$ - planned annual effect from the implementation of energy program projects.

To assess a single efficiency indicator, standard values are set, depending on the achievement of which the quality level of this indicator is determined.

On this basis, the assessment of the implementation of group efficiency indicators is determined (11), (12): 


$$
\begin{gathered}
A_{\text {group }}^{\text {tech }}=\sqrt[n]{C_{1}^{e f} \times C_{2}^{e f} \times C_{3}^{e f} \times C_{4}^{e f} \times C_{5}^{e f} \times C_{6}^{e f}} \\
A_{\text {group }}^{\text {org }}=\sqrt[n]{C_{7}^{e f} \times C_{8}^{e f} \times C_{9}^{e f} \times C_{10}^{e f}}
\end{gathered}
$$

Then the assessment of the integral criterion of the degree of fulfillment of the set goals of energy management efficiency of an industrial enterprise is determined (13)

$$
I=\sqrt{A_{\text {group }}^{\text {tech }} \times A_{\text {group }}^{\text {org }}}
$$

$A_{\text {group }}^{\text {tech }}, A_{\text {group }}^{\text {org }}$ are integral estimates of the implementation of group efficiency indicators.

The level of management efficiency is determined on the basis of the integral estimation of energy management efficiency (Table 2).

Table 9. The assessment of the integral criterion of the degree of fulfillment of the goals of energy management of an industrial enterprise

\begin{tabular}{|l|c|c|}
\hline $\begin{array}{c}\text { Level of } \\
\text { assessment of } \\
\text { energy } \\
\text { management } \\
\text { efficiency }\end{array}$ & $\begin{array}{c}\text { Formalized } \\
\text { value of } \\
\text { assessment } \\
\text { of energy } \\
\text { management } \\
\text { efficiency }\end{array}$ & \multicolumn{1}{|c|}{$\begin{array}{c}\text { Characteristics of the level of assessment of energy } \\
\text { management efficiency }\end{array}$} \\
\hline Unsatisfactory & $0<I \leq 0.5$ & $\begin{array}{l}\text { The main terms and volumes of work performed in the framework } \\
\text { of energy management are not observed, the main indicators of } \\
\text { technological efficiency indicate an insufficient level of energy } \\
\text { saving and energy efficiency }\end{array}$ \\
\hline Satisfactory & $0.5<I<1$ & $\begin{array}{l}\text { The main terms and volumes of work performed in the framework } \\
\text { of energy management are observed, the main indicators of } \\
\text { technological efficiency indicate an increase in the level of energy } \\
\text { saving and energy efficiency in accordance with the specified } \\
\text { values }\end{array}$ \\
\hline Attained & $I=1$ & $\begin{array}{l}\text { The objectives of energy management are achieved, investment } \\
\text { projects for energy saving and forming a rational fuel and energy } \\
\text { balance of an industrial enterprise are implemented. }\end{array}$ \\
\hline High & $\begin{array}{l}\text { It characterizes an intensive increase in energy consumption } \\
\text { efficiency and the release of energy resources from the fuel and } \\
\text { energy balance of an industrial enterprise. }\end{array}$ \\
\hline
\end{tabular}

To clarify the weight of individual indicators, an expert estimate can also be used, which involves general procedures for obtaining preference estimates. A survey of an expert group reveals the relative value for individual efficiency indicators.

Thus, each expert first determines a set of numbers, reflecting his/her opinion on the relative value of the i-th criterial property, and then expert estimates are calculated (14):

$$
K_{i}=m \sum_{i=1}^{m} C_{i}
$$

The final value of coefficients $\mathrm{K}_{\mathrm{i}}$ is determined by averaging the sets obtained from all experts. If the competence of experts in the group is considered the same, then $\mathrm{K}_{\mathrm{i}}=$ $\mathrm{m} \sum_{\mathrm{i}=1}^{\mathrm{m}} \mathrm{C}_{\mathrm{i}}$.

\section{Results}


In order to test the proposed methodology, an analysis of efficiency of energy management in the industry for 2018 has been conducted at the enterprises of the Tyumen region - Antipinsky Oil Refinery JSC (AOR) and SibBurMash LLC (SBM).

First of all, target values for efficiency indicators were determined based on current standards. The integral criterion of the degree of fulfillment of the goals was 0.74 for AOR and 0.68 for SBM.

The calculations of coefficients are given for 2018 and presented in Table 3.

Table 3. Target coefficients of improvement of energy efficiency of enterprises of the Tyumen region

\begin{tabular}{|l|c|c|}
\hline \multicolumn{1}{|c|}{ Single indicators of energy efficiency } & \multicolumn{2}{c|}{$\begin{array}{c}\text { Single coefficient } \\
\text { of efficiency of } \\
\text { energy } \\
\text { management }\end{array}$} \\
\cline { 2 - 3 } & AOR & SBM \\
\hline Coefficient of utilization of internal energy resources & 0.98 & 0.95 \\
\hline Coefficient of energy intensity of products & 0.75 & 0.72 \\
\hline Coefficient of the share of energy costs in the operating cost of production & 0.82 & 0.79 \\
\hline Coefficient of gross emissions of harmful substances & 0.8 & 0.71 \\
\hline $\mathrm{CO}_{2}$ emission coefficient & 0.81 & 0.66 \\
\hline $\begin{array}{l}\text { Coefficient of the share of material costs in the operating cost of } \\
\text { production }\end{array}$ & 0.95 & 0.92 \\
\hline Coefficient of implementation of investment in investment projects & 0.6 & 0.5 \\
\hline $\begin{array}{l}\text { The level of development of the competence of the industrial production } \\
\text { personnel in the field of energy saving management }\end{array}$ & 0.62 & 0.6 \\
\hline $\begin{array}{l}\text { Coefficient of timeliness of the performed works on the control points of } \\
\text { energy saving projects }\end{array}$ & 0.7 & 0.6 \\
\hline Coefficient of the effects of investment projects & 0.8 & 0.72 \\
\hline
\end{tabular}

To give a clear picture, the results of assessment of individual indicators of energy management efficiency of industrial enterprises of the Tyumen region for 2018 are presented in Figure 1. 


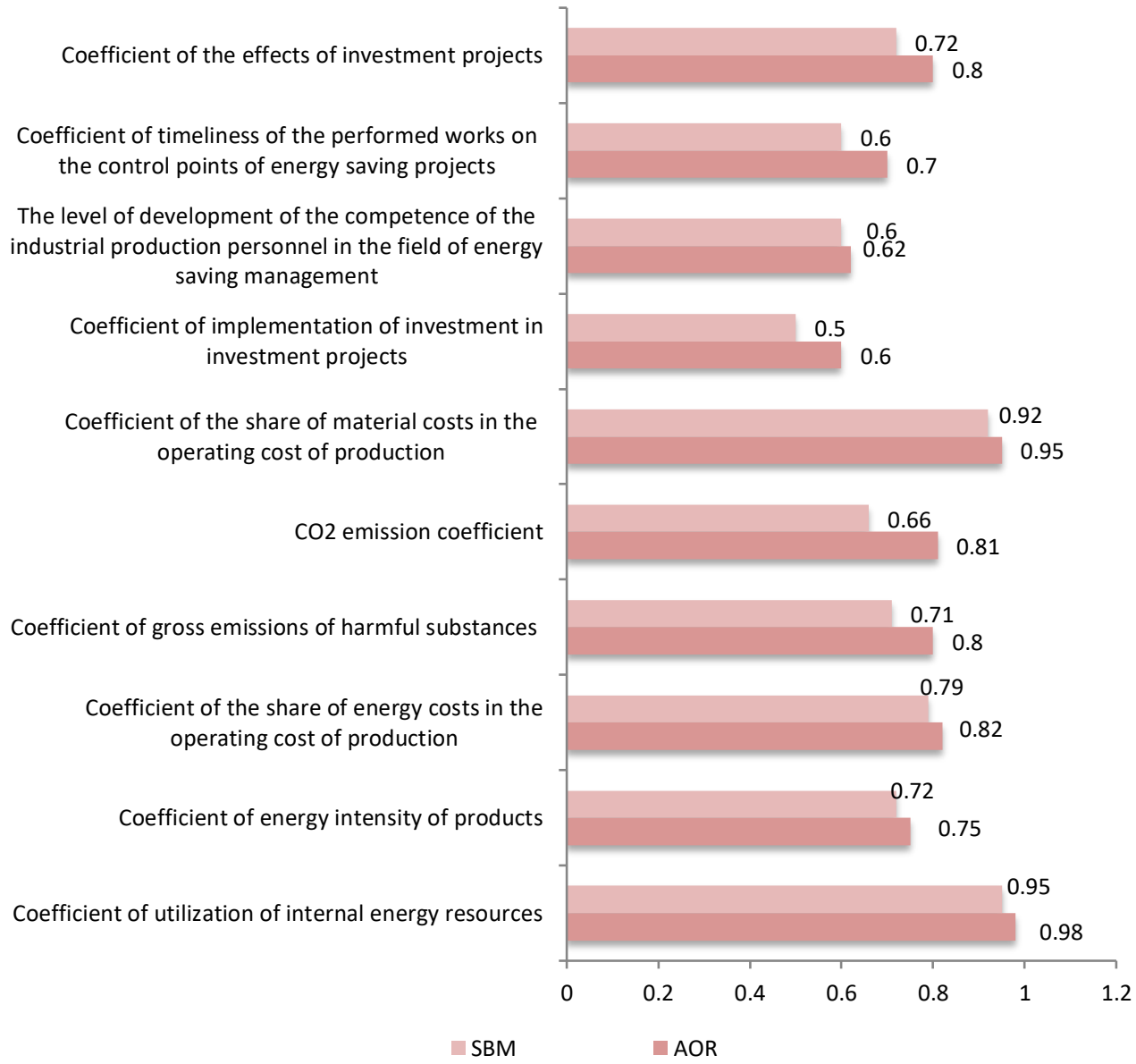

Fig. 1. Assessment of individual indicators of energy management efficiency of industrial enterprises of the Tyumen region for 2018

The results of assessment of energy management efficiency of industrial enterprises of the Tyumen region are summarized in Table 4.

Table 4. The results of assessment of energy management efficiency of industrial enterprises of the Tyumen region for 2018

\begin{tabular}{|l|c|c|}
\hline \multicolumn{1}{|c|}{ Group coefficients of energy efficiency management } & \multicolumn{2}{|c|}{ Coefficient value } \\
\cline { 2 - 3 } & AOR & SBM \\
\hline Technological efficiency indicators & 0.61 & 0.48 \\
\hline Organizational efficiency indicators & 0.46 & 0.36 \\
\hline Integral assessment of the performance of a group of indicators & 0.53 & 0.42 \\
\hline
\end{tabular}

To give a clear picture, the results of group indicators of assessment of energy management efficiency of industrial enterprises of the Tyumen region for 2018 are presented in Figure 2. 


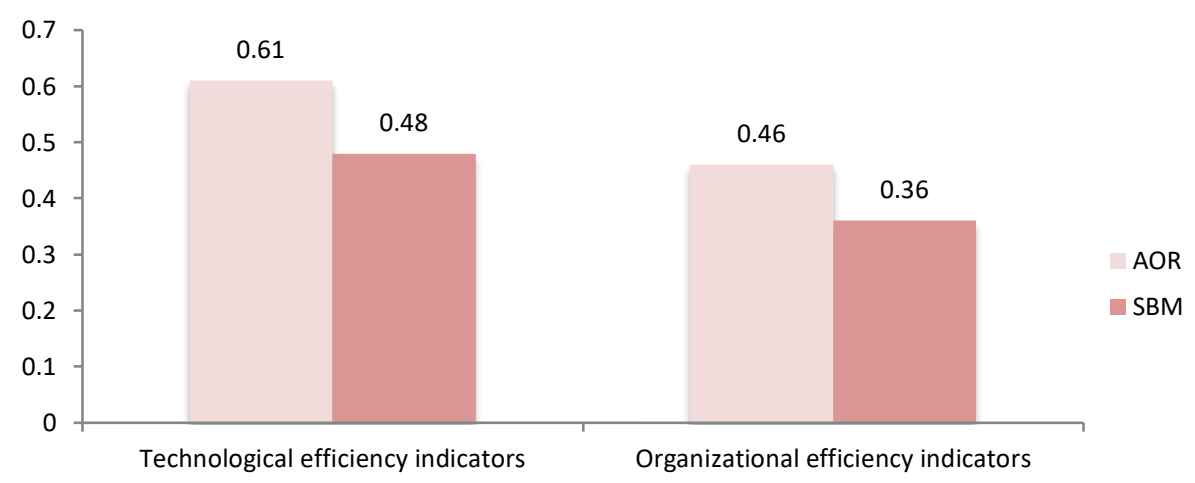

Fig. 2. Assessment of group indicators of energy management efficiency of industrial enterprises of the Tyumen region for 2018

\section{Conclusions}

Thus, we can conclude that there is an increase in technological efficiency, which is caused by the improvement of traditional technological processes and the introduction of innovative energy-saving technologies: the integrated assessment of the implementation of a group of efficiency indicators is higher than in other groups. Economic efficiency lags behind the technological one due to low rates of introduction of innovative energy-saving technologies. There is also an insufficient growth of organizational efficiency, which is due to the low quality of planning and implementation of investment projects of the program.

The methodology for assessing the efficiency of energy management at industrial enterprises will allow determining the main problem spots in this area, making decisions on their elimination and determining the main directions for improving energy efficiency.

In general, the proposed methodology allows for the ongoing monitoring of energy consumption and managing the promising energy consumption of an industrial enterprise in a comprehensive and systematic way, identifying in a timely manner the main factors affecting energy efficiency and energy saving.

\section{References}

1. V. P. Anufriev, Academy of Energy, 5(31), 36-40 (2009)

2. A. G. Vigdorchik, Energy complex of the USSR. 60-92 (1983)

3. P. L. Vilensky, Evaluation of the effectiveness of investment projects: theory and practice (Delo, Moscow 2004)

4. L. D. Gitelman, Regional energy (USTUPI, Yekaterinburg 2005)

5. A.Yu. Minnullina, Economics, 8(57), 307-311 (2009)

6. Yu. B. Klyuev, Industrial Energy, 5, 11-13(1987)

7. V. R. Okorokov, R. V. Okorokov, Academy of Energy, 5(25), 16-24 (2008)

8. M.P. Fedorov, Academy of Energy, 1(33), 4-13 (2010)

9. A. M. Afonin, Academy of Law and Management (INFA Press, Moscow 2002)

10. B. I. Ayuev, Energy market, 4, 45-50 (2007)

11. V. A. Barannik, Academy of Energy 5(43), 22-28 (2011)

12. A. Yu. Minnullina, Modern problems of management: a collection of materials of the All-Russian scientific and practical, 5, 97-102 (2015) 